\title{
TRANSLATION OF KOREAN-INDONESIAN SHORT STORIES: AN ANALYSIS OF CLASS AND SEMANTIC SHIFTS OF ADVERBS OF MODALITY
}

\author{
Nur Rosyidah Syahbaniyah', Totok Suhardijanto ${ }^{2}$
}

\author{
nur.rosyidah01@ui.ac.id1, totok.suhardijanto@ui.ac.id² \\ Program Studi Ilmu Linguistik, Universitas Indonesia \\ Depok, Jawa Barat, Indonesia
}

\begin{abstract}
This study discusses class and semantic shifts of adverbs of modality in the Korean short story and its Bahasa Indonesia translation in the short story anthology of 'Langit dan Kupu-Kupu. This study aims to identify how the adverbs of modality original text change into a different word class in the target text. The sources of data in this study were six Korean short stories entitled 'Dua Generasi yang Teraniaya', 'Seoul Musim Dingin 1964', 'Jalan ke Sampho', 'Bung Kim di Kampung Kami', 'Dinihari ke Garis Depan', dan 'Betulkah? Saya Jerapah' and its Indonesian translation. This study was conducted using a descriptive qualitative method, and the design of a linguistic corpus was used to collect analytical data. The analysis results found that from 46 adverbs of modality, four translated adverbs remained classified as adverbs. At the same time, the other ten words change their class into pronouns, nouns, particles, adjectives, and verbs. Additionally, the other 32 words have a combination of adverbs and other word classes. Furthermore, of the 290 adverb words in the source text, 143 words were accurately translated, 100 were deleted, and 47 changed their meaning in the TT. In the translation of KoreanIndonesian short stories, the shifting technique is used to adjust differences between Korean and Indonesian grammar systems. Translators also make a shift in the word's meaning of short stories as long as they do not deviate from the context and message in the ST to produce a natural translation that TL readers can easily understand.
\end{abstract}

Keywords: Modal Adverbs Translation, Korean Short Story, Class Shifts, Semantic Shifts, Corpus Linguistics

\section{INTRODUCTION}

Literary works reflect the culture of a nation. We can find out the works' cultural, historical, and social backgrounds from the literary works. Unsurprisingly, literary works are frequently used to promote a country's culture to other countries. Novels and short stories are the most widely disseminated literary works, mainly because they have an entertaining storyline and characterizations that the public can enjoy reading. In the novels and short stories, the authors combine cultural, historical, and social elements from their direct experiences and observations as extrinsic elements that shape the storyline. Dissemination of literary works, especially novels and short stories, is inseparable from translation. The translation of novels and short stories facilitates people to understand and enjoy the stories without independently translating the texts. Nevertheless, literary translation of novels or short stories has two main challenges, namely the challenges in linguistic elements and literary elements. The linguistic elements include the language system between the source language (SL) and the target language (TL), while the literary elements include plot, characterizations, themes, conflicts, etc.

One of the linguistic elements considered in literary translation is shifts in word-class and meaning. The shift is unavoidable in translation because, principally, no language in the world is identical, so a shift is necessary to 
adjust the convention from SL to TL. The shifts in translation occur to find equivalence between the source text (TS) and the target text (TS), which involves both languages with different structures and cultural backgrounds. A qualitative study conducted by Mardiana (2014) using a short story entitled 'My Beloved Edith' in English and its translation into Indonesian revealed that the transposition and modulation techniques used by the translators lead to translation shifts to achieve equivalence of meaning and message. The shifts found in the short story text are a structural, unit, category, and perspective shifts from active in SL to passive in TL. This study was conducted using the observation method to collect data.

The data analysis to track the translation shifts can be performed using listening and note-taking techniques. The listening method is used to scrutinize spoken and written language, while the note-taking technique is used to record the relevant parts as the research object. The Japanese language has a different language convention from the Indonesian language. Therefore, research that traces morphemic and semantic shifts between source texts (ST) in the Japanese language and Target Text (TT) in the Indonesian language is exciting. Based on a study on class and semantic shifts in the translation of Akutagawa Ryunosuke's 'Kappa' short story, it was found that there were 72 words that experienced the class shift. The most frequent class shift was adverbs with 27 data, followed by verbs with 24 data, nouns with 11 data, and adjectives with 10 data (Krisna et al., 2018).

According to Machali, four factors cause shifts in translation: the language systems and rules that require shifts, the differences in the lexical structure between the language of ST and TT, achieving flexibility in the TT, and filling the lexical gap in the TT (Machali, 2009). Catford (1965) defines translation shift as a change in linguistic form. He suggested that a "shift in translation" is a shift in formal correspondence in the process of transferring text from the source language (SL) to the target language (TL) to make translation results acceptable. Changes or shifts often occur in translation, at the word, phrase, clause, and sentence level. Baker (Gottlieb et al., 1998) defines shift as a change in the meaning between SL and TL. Every time they do a translation, the translators choose one of several available meanings to make translation acceptable and easily understood by the TT readers. However, the translators often alter the meaning of a word in the source text during the translation into the target text or choose not to translate the word. This shift or deletion of meaning is performed to preserve the messages in ST and make them easily perceived by the TL readers.

The Korean language has different language conventions from the Indonesian language, as seen from the differences in their letters, patterns of sentence structures, and the grammatical system. This becomes a compelling reason to compare the grammatical system between Korean and Indonesian, one of which is adverbs. In Korean and Indonesian, adverbs have more or less the same types, including adverbs of time, degree, and modality. A study conducted by Jayanti found that the most profound difference between the three types of adverbs in Korean and Indonesian is a difference in meanings. Several adverbs in Korean can be interpreted or translated into the same adverb in Indonesian (Jayanti, 2019). For example, the term '방금 (banggeum)' and '아까 (akka)' are adverb of time when translated into Indonesian these two words become the same word, namely 'tadi' (just). This identical meaning can be seen in the following example.

\section{1 (a). 니아가 방금 학교에 갔다. \\ (Nia-ga banggeum hakkyo-e gatda.) \\ Nia tadi pergi ke sekolah. \\ (Nia just had gone to school) \\ 1 (b). 니아가 아까 학교에 갔다. \\ (Nia-ga akka hakkyo-e gatda.) \\ Nia tadi pergi ke sekolah. \\ (Nia had gone to school a while ago)}

Although both words have identical meanings, they are slightly different in Korean. For example, '방금 (banggeum)' has a shorter timeframe than '아까 (akka).'This difference can be identified once we look up the meaning of these words in the dictionary, as shown in the following table.

Table 1. Meaning of '방금 (banggeum)' and '아까 (akka)'

Word Meaning




\author{
방금 (banggeum) 말하고 있는 시점보다 \\ 바로 조금 전에. (just \\ before the point in time \\ the subject talks.) \\ 아까 (akka) 조금 전에. (a while ago.) \\ Source: Online Dictionary 'Naver Korea'
}

Suppose we refer to the meaning of '방금 (banggeum)' and '아까 (akka)' above, the sentence 1(a) '니아가 방금 학교에 갔다. (Niaga banggeum hakkyo-e gatda.)' Implies that Nia just had gone to the school. Meanwhile, the sentence $1(\mathrm{~b})$ '니아가 아까 학교에 갔다. (Niaga akka hakkyo-e gatda.)' Implies that NImpliesgone to the school a while ago. Furthermore, the word 'tadi,' according to the Great Dictionary of Indonesian Language (KBBI), is not classified as an adverb but a noun. A further example is the adverbs of modality '정말 (jeongmal)' have two meanings in two different words classes. The first meaning is 'benar-benar (really),' an adjective, while the other is 'sungguh-sungguh (truly),' an adverb. However, placed into a sentence, these two meanings do not significantly differ, as shown in the following sentence below.

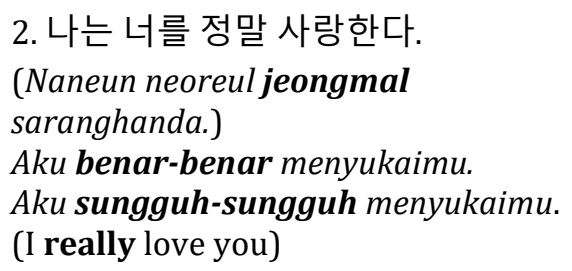

Adverbs of modality are divided into several types according to their function in a sentence. Research on the type of adverbs of modality in the translated text can only be conducted by inspecting the TT. However, through the listening and note-taking techniques, it is possible to find adverbs that indicate modality in the TT as the data that will subsequently be analyzed for its class. Based on research conducted by Fatiha, it was found that the types of adverbs of modality in the translation of the Qur'an include the modality of affirmation/certainty, doubt, desire, invitation, obligation, prohibition, denial, interdependence, and determination (Fatiha et al., 2018).

Adverbs in Indonesian is a word class that can modify adjectives, numerals, or propositions in syntactic construction. Adverbs have a function to explain: 1) Aspects, such as a job, an event, situation, or a nature that can occur (durative), has been occurred (perfective), has not been occurred (imperfect), or is just beginning to take place (inchoative); 2) Modalities, which explains the attitude or atmosphere of the speaker regarding the conversation, event, situation, or nature; 3) Quantities, which describes the frequency or number of occurrences of the event, condition, and nature; and 4) Qualities, which explains the nature or value of the act, event, condition, or nature. Adverbs of modality generally reflect the psychological state of the narrator. According to Min and Wang, adverbs of modality or in Korean called 양태부사 (yangtae busa) is an adverb that expresses various attitudes of the narrator towards the narrative (Wang \& Min, 1993). The features of adverbs of modality in Korean, according to Lee, Hu-in include modifying the entire sentence, lying at the beginning of a text or sentence, in some cases moving its position in the middle of the sentence, and responding to some final affix particles and possibly having syntactical limitations on several suffix forms (Lee, 2015).

Adverbs of modality in Korean can be recategorized based on their respective functions. Min, Hyun Sik divides adverbs of modality into three significant subcategories, namely 서실법 (seosilbeop, reality or objectivity), 서상법 (seosangbeop, non-reality or subjectivity), and 성의법 (seongibeop, desire). These categories are divided into smaller-sub category namely, 당위 (dangwi, absolute), 필연 (pilyeon, need), 확신 (hwaksin, certainty), 확인 (hwakin, confirmation), 의문 (euimun, question), 부정 (bujeong, denial), 추측 (chucheuk, estimation), 가정 (gajeong, assumption), 양보 (yangbo, consensus), 평가 (pyeongga, evaluation), 간구 (gangu, request), and 명령 (myeongryeong, command). These twelve subcategories are further divided into several categories based on their function in a sentence. Thus, there are 36 categories of adverbs of modality (Min, 1999). In addition, 
there are different categories according to Son and Jang. Son (1995) divides adverbs of modality into nine categories, namely 가정 (gajeong, assumption), 강조 (kangjo, emphasis), 부연 (buyeon, amplification), 의혹 (euihok, doubt), 이유 (iyu, reason), 전환 (jeonhwan, diversion), 추정 (chujeong, assumption), 확실 (hwaksil, certainty), and 부정 (bujeong, rejection). Meanwhile, Jang (1994) categorizes adverbs of modality into 확인성 부사 (hwakinseong busa, adverb of confirmation), 조건성 부사 (jogeonseong busa, adverb of requirement), 당위성 부사 (dangwiseong busa, adverb of absoluteness), 유사성 부사 (yusaseong busa, adverb of similarity), 추측성 부사 (chucheukseong busa, adverb of presumption), 강조성 부사 (kangjoseong busa, adverb of emphasis), 의문성 부사 (euimunseong busa, adverb of interrogative), 소원성 부사 (sowonseong busa, adverb of wish), and 유보성 부사 (yuboseong busa, adverb of postponement). In these three types of adverb categorizations, several adverbs of modality are the same. However, some other types of adverbs of modality differ among the categorizations. In addition, different word lists for the same type of adverbs of modality can also complement each other so that the authors use these three types of categorizations in the data analysis.

Adverbs generally provide information to other word classes and modify a sentence. Therefore, translation shifts in the class and meaning of adverbs to conform to the TL convention led to changes in their function in TT or perhaps to deletion of them. Adverbs of modality are very closely related to the narrator's attitude, thereby raising the question of whether class shifts and semantic shifts of an adverb in the translation from ST to TT distort the message content of a short story. The previous studies on the translation shift used the ST in English and Japanese and the Indonesian TT. However, no study focused on the shifting technique in Korean literary text and its Indonesian translation for data analysis.
Also, the previous studies discussing adverbs of modality focused only on a single language, analyzing adverbs of modality found in Arabic and Korean text and did not compare the adverbs between the ST dan TT. Therefore, the author analyzes the class shift and semantic shift of adverbs of modality in the Korean short stories and their translations compiled in the short story anthology of 'Langit dan KupuКири' in Indonesian. The questions in this study are how the class shift of adverbs of modality in the short story anthology of 'Langit dan Кири-Кири' in Korean and their translations, and how semantic shift of adverbs of modality in the short story anthology of 'Langit dan Kupu-Kupu' in Korean and their translations occurs.

\section{METHOD}

In this study, the author used a corpus linguistic approach in collecting and analyzing data. Corpus linguistics studies language data (both spoken and written) on a large-scale using computers to store and analyze data (McEnery \& Hardie, 2011). Baker suggested several types of the corpus can be used for translation research, namely parallel corpora, comparable corpora, and multilingual corpora (Baker, 1995).

This study research used a qualitative descriptive method. Six short stories in Korean and their translations in Indonesian that compiled in of translated-Korean short story anthology of 'Langit dan Kupu-Kupu' by Koh Young Hun and Tommy Christomy (Koh et al., 2007) were used as research data. The six short stories are 하근찬 - 수난 이대 (Ha Geun-chan Sunan Idae, Dua Generasi yang Teraniaya), 김승옥 - 서울 1964 년 겨울 (Kim Seung-ok Seoul Cheongubaekyuksipsanyeon Gyeoul, Seoul Musim Dingin 1964), 황석영 - 삼포가는길 (Hwang Seokyeong - Sampho Ganeun Gil, Jalan ke Sampho), 이문구 - 우리동네 김씨 (Lee Mungu - Uri Dongne Kimssi, Bung Kim di Kampung Kami), 방현석 - 새벽출정 (Bang Hyeon-seok Saebyeok Chuljeong, Dinihari ke Garis Depan), and 박민규 - 그렇습니까? 기린입니다 (Park Min-kyu - Geureohseumnikka? Girinimnida, Betulkah? Saya Jerapah). Through this corpus of six short stories, class and semantic shifts of adverbs of modality were explored further in 
this study. The corpus data were collected from an eBook of six Korean short stories and their printed translations, then combined into a parallel corpus. The six Korean short stories, original texts, were entered in the same column and separated by sentence. Furthermore, the translated text was entered into the column right to the original text column and separated by sentence. Each short story text was displayed in parallel to its meaning in a single excel file. Subsequently, the file was uploaded to the Sketch Engine ${ }^{\circledR}$ (Kilgarriff et al., 2014). The SL corpus consists of 32,034 words, while the TL corpus consists of 37,906 words. The Sketch Engine features used in this study were Wordlist and Parallel Concordance.

The Wordlist feature filtered out the adverb word classes in the SL corpus. Next, adverbs found in the Wordlist were filtered again to find adverbs of modality based on the lists of Min (1999), Son (1995), and Jang (1994). The lists of adverbs of modality from SL were then translated using the Daum KoreanIndonesian online dictionary (https://dic.daum.net/index.do?dic=id) and the Korean-Indonesian Naver online dictionary (https://dict.naver.com/idkodict/\#/main).

Afterward, the word class of Indonesian meaning from the word list was looked up using the Great online Dictionary of Indonesian Language

(https://kbbi.kemdikbud.go.id/Beranda). The word class found was subsequently compared between the SL word list and its translation in TL to determine the class shift. Furthermore, each of the adverbs of modality that has been found was looked up using the Parallel Concordance feature to see its position in the SL sentence and directly compares its translation in the SL to identify the shift in their meaning.

\section{RESULT AND DISCUSSION}

\section{Class Shift of Adverbs of Modalities}

Through the Wordlist feature in the Sketch Engine ${ }^{\circledR}, 515$ adverbs were found with a total frequency of 2,448 in the corpus of six short stories that were analyzed. The list of adverbs is sorted based on the frequency of appearance in the corpus. Display of wordlists of adverbs from the research corpus can be seen in the figure below.

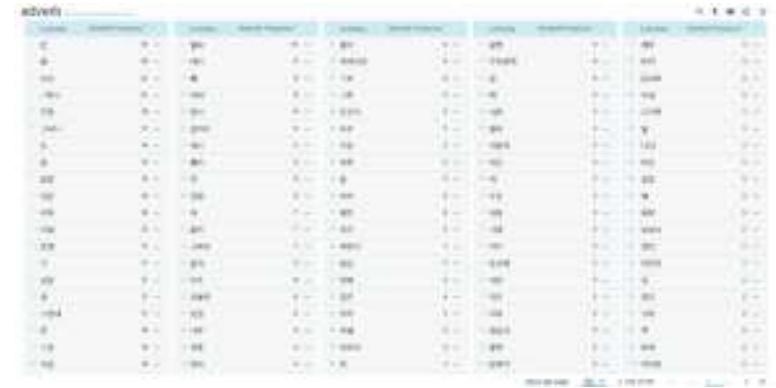

Figure 1. Adverb Wordlist Display on Sketch Engine ${ }^{\circledR}$

After further analysis of 515 adverb words using the list of types of adverbs of modality according to Min (1999), Son (1995), and Jang (1994), there were 46 adverbs found in the ST categorized as adverbs of modality. The adverbs of modality that have been found are rearranged in the table based on their function. The following table consists of the list of adverbs of modality found from the six short stories in the SL that were analyzed.

Table 2. Lists of adverbs of modality

\begin{tabular}{|c|c|}
\hline Types of Modality & List of words \\
\hline \multirow[t]{3}{*}{$\begin{array}{l}\text { Absoluteness/Mu } \\
\text { st }\end{array}$} & $\begin{array}{l}\text { 꼭 (kkok), 물론 (mullon), } \\
\text { 반드시 (bandeusi), 틀림없이 }\end{array}$ \\
\hline & (theullimeobsi), \\
\hline & $\begin{array}{l}\text { (gieokho), } \\
\text { (dangyeonhi) }\end{array}$ \\
\hline \multirow[t]{4}{*}{$\begin{array}{l}\text { Certainty/Emphas } \\
\text { is }\end{array}$} & $\begin{array}{lr}\text { 결국 (gyeolguk), } & \text { 실은 } \\
\text { (sireun), } & \text { 분명히 }\end{array}$ \\
\hline & (bunmyeonhi), \\
\hline & (amutheun), 사실 (sasil), \\
\hline & 왁실이 (hwaksilhi) \\
\hline Confi & $\begin{array}{l}\text { 정말 (jeongmal), } \\
\text { (yeoksi), 하긴 (hagin) }\end{array}$ \\
\hline $\begin{array}{l}\text { Quest } \\
\text { ative }\end{array}$ & $\begin{array}{l}\text { 왜 (wae), 어찌 (eojji), 어째 } \\
\text { (eojjae) }\end{array}$ \\
\hline \multirow[t]{2}{*}{ Denial/Emphasis } & $\begin{array}{l}\text { 도대체 (dodaeche), 도저히 } \\
\text { (dojeohi), 비록 (birok), 결코 } \\
\text { (gyeolkho), 전혀 (jeonhyeo), }\end{array}$ \\
\hline & $\begin{array}{l}\text { 차마 (chama), } \\
\text { (domuji), 통 (thong) }\end{array}$ \\
\hline \multirow{2}{*}{$\begin{array}{l}\text { Presumption/Esti } \\
\text { mation }\end{array}$} & 아마 (ama), 아무리 (amuri), \\
\hline & $\begin{array}{l}\text { 어쩌면 (eojjeomyeon), } \\
\text { (hok), 행여 (haengyeo) }\end{array}$ \\
\hline $\begin{array}{l}\text { sumption/Requ } \\
\text { ment }\end{array}$ & (manyak), \\
\hline
\end{tabular}




\begin{tabular}{|c|c|}
\hline Concession & $\begin{array}{l}\text { (amuri), 비록 (birok), 설마 } \\
\text { (seolma) } \\
\text { 비록 (birok) }\end{array}$ \\
\hline Evaluation & $\begin{array}{l}\text { 오히려 (ohiryeo), 차라리 } \\
\text { (charari), 다행히 (dahaenghi) }\end{array}$ \\
\hline Request/Wish & $\begin{array}{l}\text { 제발 (jebal), 부디 (budi), } \\
\text { 아무쪼록 (amujjorok) }\end{array}$ \\
\hline Command & 어서 (eoseo) \\
\hline Amplification & $\begin{array}{l}\text { 게다가 (gedaga), 하긴 (hagin), } \\
\text { 말하자면 (malhajamyeon) }\end{array}$ \\
\hline Doubt & $\begin{array}{l}\text { 어쩐지 (eojjeonji), 설마 } \\
\text { (seolma) }\end{array}$ \\
\hline Similarity & 마치 (machi) \\
\hline Postponement & $\begin{array}{l}\text { 여하튼 (yeohatheun), 아무튼 } \\
\text { (amutheun), } \\
\text { (eojjaetdeun) }\end{array}$ \\
\hline
\end{tabular}

From 46 adverb on the above lists, there were 4 words that remain classified as adverb after being translated into Indonesian, namely, 실은 (sireun) that means 'sebenarnya (actually), sesungguhnya (really)'; 어쩌면 (eojjeomyeon) that means 'alangkah (what a/an..), barangkali (maybe), mungkin (possibly)'; 당연히 (dangyeonhi) that means 'memang (indeed), sewajarnya (naturally), semestinya (necessarily)'; and 사실 (sasil) 'sebenarnya (in fact), sesungguhnya (truly)'. Meanwhile, there 8 words that changes their class. Those are 왜 (wae) that means 'mengapa/kenapa (why) (pronoun)'; 만약 (manyak) that means 'jika/apabila (if) (particle/pronoun)'; 아무리 (amuri) that means betapapun (no matter how) (pronoun/particle + particle)'; 비록 (birok) that means 'meskipun/sekalipun/biarpun (although) (particle)'; 다행히 (dahaenghi) that means 'untungnya/beruntung (fortunately) (nominal/adjective, verb)'; 제발 (jebal) that means 'demi Tuhan (for the God's sake), tolonglah (please) (particle + nominal, verb)'; 어찌 (eojji) that means 'mengapa (why), bagaimana (how) (pronoun)'; and the word 부디 (budi) that means 'mohon/harap/tolong (please) (verb, verb/nominal)'. According to Machali, factors causing the shift of translation include the difference in the grammatical structure between Korean and Indonesian. Therefore, some adverbs of modality in Korean can be classified into other word classes when translated into Indonesian.

Finally, 34 words have mixed classes: adverbs with pronouns, nouns, particles, adjectives, numerals, and verbs.

\section{Class Shifts of Adverbs of Modality}

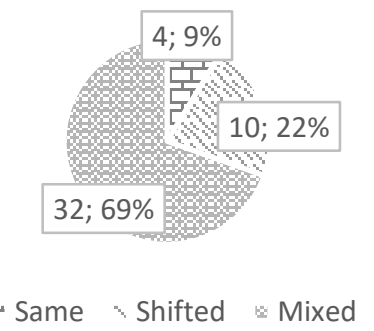

Figure 2. Diagram of Class Shifts of Adverbs of Modality

This combined word class is identified because such a single Korean adverb can have a meaning consisting of two or more words in Indonesian. Furthermore, in line with the research results conducted by Jayanti, a single adverb in the ST tends to have several meanings in the TL so that each meaning can have different word classes. For instance, '도저히 (dojohi)' means 'bagaimanapun juga' (absolutely). The word 'bagaimanapun' is a particle, while 'juga' is an adverb. Therefore 'bagaimanapun juga' comprises a particle and an adverb. Furthermore, the word '반드시 (bandeusi)' has several meanings 'pasti' /'tentu' and 'tentu saja' (indeed). Therefore, each of these Indonesian words has a different word class. The word 'pasti' is an adjective, while 'tentu' can be either an adjective or an adverb, and the word 'saja' is an adverb. Therefore, translated into Indonesian, the word '반드시 (bandeusi)' belongs to a different word class of adjective (pasti), adjective/adverb (tentu) + adverb (saja).

\section{Semantic Shifts of Adverbs of Modalities}

From the list of adverbs of modality that have been found in the ST, the adverbs were then searched using the Parallel Concordance to compare their meanings between the ST and 
context. Semantic shifts lead to a very different meaning of '정말 (jeongmal)' in the TT, yet this did not alter the story's context. As in the first sentence in the table below, '정말 (jeongmal)' means 'berat (so sorry). 'The word 'berat' was the meaning of the clause '정말 덜 좋았다 (jeongmal deol johatda)' if translated to 'dia benar-benar merasa kurang enak (he's really sorry).'The translator later changed the phrase 'benar-benar kurang enak (really sorry)' to be heavy .'Additionally, the meaning 'berat,' of the word '정말 (jeongmal)' also experienced a shift in its meaning into 'justru,' 'mungkin,' 'bakal,' and 'lagi.'

Table 5: Analysis (3)

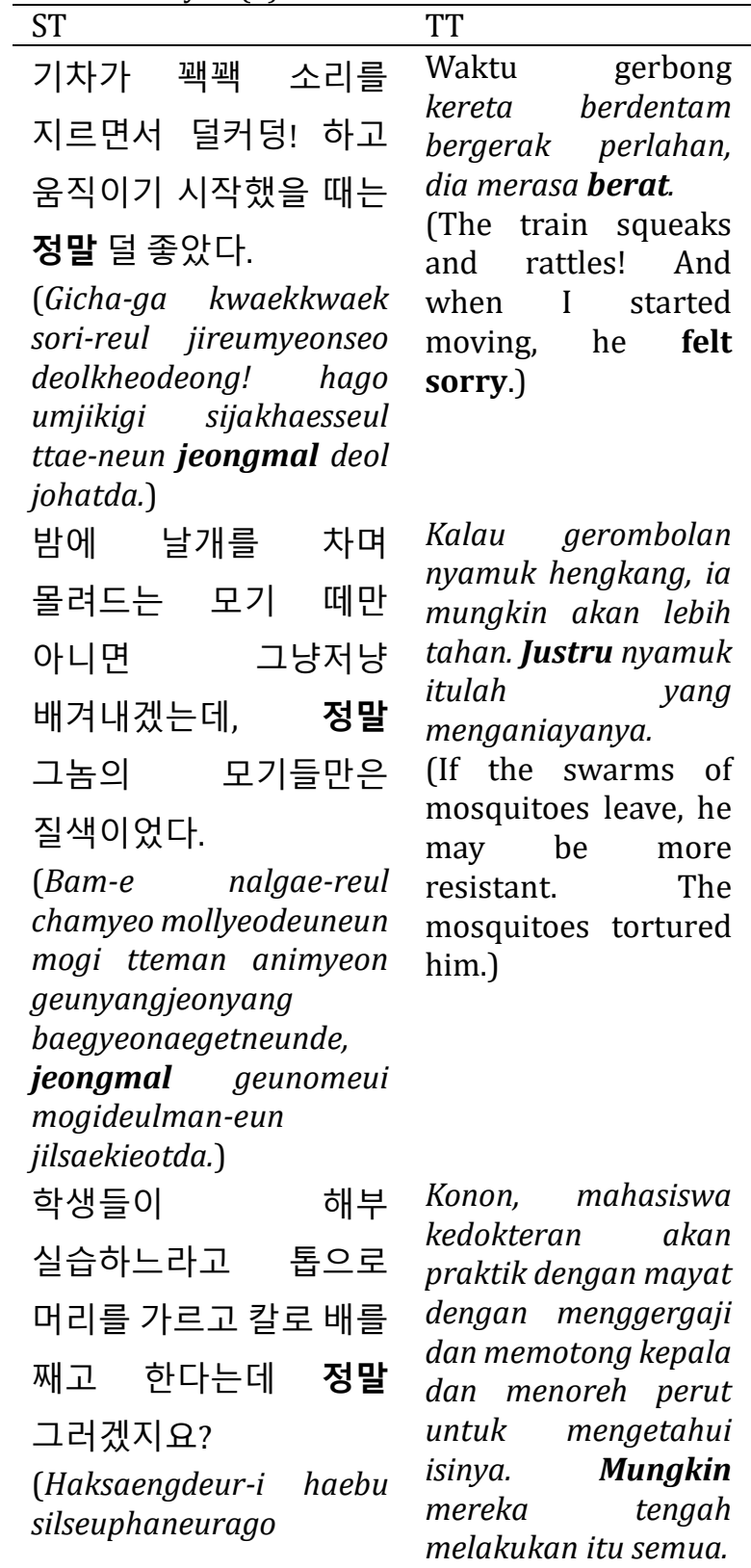

topeuro meori-reul (Medical students gareugo khal-lo bae-reul would practice jjaego handaneunde dissection with a jeongmal geureogetjiyo?) dead body by sawing and cutting off the head and incising the stomach to find out what was inside. Maybe they're doing it all.)

"야 되게 많네. 정말 "Wah banyak banget. 든든하시겠구만." Situ bakal aman."

(That's a lot. You will ("Ya dwoege manhne. really be safe) Jeongmal deundeunhasigetguman.")

이젠 정말 싸우는 게 Sekarang saya tidak 자신이 없어요.

(Ijen jeongmal ssauneun (Now I am not sure ge jasin-i eobseoyo.) anymore I can fight here.)

Furthermore, the word '정말 (jeongmal)' was also deleted in some sentences in the TT. This deletion was probably performed for several reasons, such as to avoid confusion, and because the translated context had been clear without having to translate the words '정말 (jeongmal)', and to fit the context as the presence of '정말 (jeongmal)' make the context unclear or incomprehensible to the reader indeed. The deletion occurs in 6 sentences that contain the word '정말 (jeongmal)' in ST. The following table provides the example of '정말 (jeongmal' in the ST that was discarded during the translation.

Table 6: Analysis (4)

\begin{tabular}{|c|c|c|}
\hline \multicolumn{2}{|l|}{ ST } & TT \\
\hline 햇덩어리가 & 어쩌면 & \multirow{2}{*}{$\begin{array}{l}\text { Alangkah besar dan } \\
\text { merahnya sang surya itu. }\end{array}$} \\
\hline 그렇게 크고 & 붉은지 & \\
\hline \multirow{2}{*}{\multicolumn{2}{|c|}{$\begin{array}{l}\text { 정말 처음이었다. } \\
\text { (Haetdeongeori-ga } \\
\text { eojjeomyeon geureohke } \\
\text { kheugo bulgeunji } \\
\text { jeongmal } \\
\text { choeumieotda.) }\end{array}$}} & \multirow[t]{2}{*}{$\begin{array}{l}\text { (What a big and red the } \\
\text { sun) }\end{array}$} \\
\hline & & \\
\hline \multicolumn{2}{|c|}{$\begin{array}{l}\text { 그럴 때는 정말 질겁을 } \\
\text { 하는 것이었다. }\end{array}$} & $\begin{array}{l}\text { Saat itu mereka } \\
\text { terperanjat. }\end{array}$ \\
\hline $\begin{array}{l}\text { (Geureol } \\
\text { jeongmal }\end{array}$ & $\begin{array}{l}\text { ae-neun } \\
\text { eop-eul }\end{array}$ & $\begin{array}{l}\text { (At that time, they were } \\
\text { creepy.) }\end{array}$ \\
\hline
\end{tabular}


haneun geosieotda.)

엄동설한에 정말 갈데

없이 빳빳하게

됐는데요.

(Eomdongseolhan-e

jeongmal galde eobsi

ppatppathage

dwaetneundeyo.)

The shift in the meaning of adverbs was found in all sentences that contained the adverbs of '결코 (kyeolkho)' in the ST corpus. This adverb is translated by changing its original meaning, which is 'pasti (definitely), jelas (clearly), 'sama sekali tidak (not at all) .'This shift was performed by implicitly emphasizing the meaning of 'sama sekali tidak' and 'pasti' on the meanings of 'tidak (no)' and 'bukanlah (not).'This was performed to shorten the sentence because the words 'tidak' and 'bukanlah' already represent the entire meaning of the word '결코 (kyeolkho) .'A shift can occur to achieve flexibility in the TT. Even though the meaning of the word '결코 (kyeolkho)' in TT shifted, the resulting meaning still preserves the context and message conveyed in ST.

Table 7: Analysis (5)

\begin{tabular}{|c|c|}
\hline ST & TT \\
\hline 말하자면 & Dengan kata lain, Bung \\
\hline 돌았다고 할 수 있는 & $\begin{array}{l}\text { ini agak sinting } \\
\text { sebenarnya }\end{array}$ \\
\hline 사람이지만 나쁜 & sekali) tidak melakukan \\
\hline 짓을 결코 하지 않는 & kejahatan apa pun. \\
\hline 장사꾼입니다. & (In other words, this \\
\hline (Malhajamyeon jom & he \\
\hline doratdago hal su & $\begin{array}{l}\text { actually did not commit } \\
\text { any crimes at all.) }\end{array}$ \\
\hline $\begin{array}{lr}\text { nappeun } & \text { jiseul }\end{array}$ & \\
\hline kyeolkho haji & \\
\hline anhneun & \\
\hline jangsakkunimnida.) & \\
\hline 결코 사장과 & Presiden direktur dan \\
\hline 자신들은 같은 줄에 & $\begin{array}{l}\text { mereka (sama sekali) } \\
\text { tidak bisa duduk di satu }\end{array}$ \\
\hline 서 있을 수 없음을, 7 , & meja. Mereka telah \\
\hline 8 년이 아니라 70 년 & duduk mereka hanya di \\
\hline 80 년을 다녀도 & kursi murah saja \\
\hline 그들이 서야 할 줄은 & $\begin{array}{l}\text { walaupun tujun pulun } \\
\text { dan delapan puluh tahun } \\
\text { mengabdi sekali pun. }\end{array}$ \\
\hline
\end{tabular}

노동자의 대열임을

뼈아프게

확인하였다.

(Kyeolkho sajanggwa jasindeureun gatheun jure seo iseul su eobseumeul, 7, 8nyeondi anira 70nyeon 80nyeoneul danyeodo geudeuri seoya hal jureun nodongjaeui daeyeorimeul ppyeoapheuge hwakinhayeotda.)

그러나 그것은 결코

사장에 대한

치욕스런

항복문서만은

아니었다.

Namun, surat itu (jelas)

bukanlah surat

kekalahan mereka.

However, the letter was (clearly) not their letter of defeat.

(Geureona geugeoseun kyeolkho sajan-e daehan chiyokseureon hangbokmunseomaneun anieotda.)

감독이 빈정댔지만

그는 결코 얼굴을

들지 않았다.

(Gamdok-i

binjeongdaetjiman

geu-neun kyeolkho

eolgur-eul deulji

anhatda.)

From 46 adverbs of modality found in this Korean short story anthology corpus, 290 sentences contain adverbs of modality. Overall, most of them were translated without shifting their meaning into TT. This can be achieved as an adverb word in Korean can have several meanings in Indonesian so that the translators are free to choose the appropriate meaning and maintain its meaning. In addition, the translators also carry accurate adverb translation to maintain the context and message in the ST.

Furthermore, the deletion also tends to be performed by the translators in translating sentences that contain adverbs of modality in the ST. The deletion of meaning is intended to avoid misunderstandings if the word is still translated and prevent confusion in the 
translated text. Finally, there are some semantic shifts found in the TT. The shift in the meaning occurs to achieve flexibility and fill lexical gaps in TT, as Machali stated in her theory. The translator performs this shift to adjust the meaning to the context to be more understandable by the target reader without distorting the message content in the ST. As Baker stated, the deletion and shift in the meaning occurred to maintain the ST's message contents and make them more natural so the reader can understand the message more clearly.

Semantic Shifts of Adverbs of
Modality
Figure 4. Diagram of Semantic Shifts of Adverbs of
The class shift of adverbs of modality
Korean to Indonesian occurs more
from
frequently than the semantic shift. This occurs
because of different language systems between
Korean and Indonesian that make the
differences in form and word-class between
the two languages unavoidable. Furthermore,
the adverb of modality in Korean can have
several meanings in Indonesian and can be

classified into some different word classes. This results in a mixture of word classes in Korean adverbs of modality translation. Such diverse meanings also reduce the likelihood of the semantic shift because the translators have several choices of meaning to fit the context when translating it into TT.

\section{CONCLUSION}

Short story translation is a literary translation process that is closer to TL. In the translation of Korean-Indonesian short stories, the shifting technique is used to find equivalence in a different grammatical system between the Korean and Indonesian languages. Translated into TT, adverbs automatically follow the rules in the TL so that the translation can change the word class from adverb to another word class. Translators also sometimes alter the meaning of a word in short stories as long as it does not deviate from the context and message in the ST to produce a natural short story translation that TL readers can easily understand. Therefore, this shifting technique produces a more contextual translation and looks more natural for readers. This research is limited to finding out how the class and semantic shifts of adverbs of modality in six Korean short stories and their translations. Future studies need to trace the class and semantic shifts of other word classes and analyze the procedures and strategies used in translating Korean short stories into Indonesian.

\section{REFERENCES}

Baker, Mona. (1995). Corpora in Translation Studies: An Overview and Some Suggestions for Future Research. Targets. 7, 223-243. https://doi.org/10.1075/target.7.2.03bak (1998). Routledge Encyclopedia of Translation Studies. Routledge.

Bang, H. (1989). Saebyeok Chuljeong. Creation \& Criticism. 17(1), 233-276.

Catford, J. C. (1965). A linguistic theory of translation: An essay in applied linguistics. Oxford University Press.

Futih, F.F.F. (2018). Makna Adverbia Penanda Modalitas Pada Teks Terjemahan Alquran (TTA) [Tesis, Universitas Muhammadiyah Surakarta]

Ha, G. (1993). Sunan Idae. Eomungak. 
Hwang, S. (1995). Sampho Ganeun Gil. Donga Chulpansa.

Jang, Y. (1994). Jeopsok Busa-e Daehayeo. 語文論集. 4, 137-154.

Jayanti, M. (2019). Adverb Comparison of Korean and Indonesian Languages [Tesis, Silla University].

Kilgarriff, A. et al. (2014). The Sketch Engine: Ten Years On. Lexicography, 1(1), 7-36. https://doi.org/10.1007/s40607-014-0009-9 (http://www.sketchengine.eu)

Kim, S. (2006). Seoul 1964-nyeon Gyeoul. Malgeun Sori.

Koh, Y. H., Christomy, T., \& Rangkuti, H. (2007). Laut dan Kupu-kupu: Kumpulan Cerpen Korea. Gramedia Pustaka Utama.

Krisna P, N. (2018). Pergeseran Bentuk dan Makna Terjemahan dalam Cerpen Kappa Karya Akutagawa Ryunosuke. Humanis, 22(4), 1009-1017. doi:10.24843/JH.2018.v22.i04.p24

Lee, H. (2015). A Study on Modal-conjunctive Adverbs in Korean [Disertasi, Seoul University]. SNU Open Repository. https://hdl.handle.net/10371/132138

Lee, M. (1978). Uri Dongne Kim-ssi. Hanjin Chulpansa.

Machali, R. (2009). Pedoman bagi Penerjemah: Panduan Lengkap bagi Anda yang Ingin Menjadi Penerjemah Profesional. PT Mizan Pustaka.

Mardiana, W. (2014). Teknik Transposisi dan Modulasi: Kesepadanan dan Pergeseran dalam Penerjemahan Cerpen Berjudul "My Beloved Edith". PAROLE: Journal of Linguistics and Education, 4(2 Oct), 120-130.

McEnery, T., \& Hardie, A. (2011). Corpus linguistics: Method, theory, and practice. Cambridge University Press.

Min, H. (1999). Gugo Munbeop Yeongu. Yeongnak.

Park, M. (2004). Geureohseumnikka? Girinimnida. Creation \& Critisism. 32(3): 233-251.

Son, N. (1995). Gugo Busa Yeongu. Pagijong Press, Inc.

Wang, M. \& Min, H. (1993). Gugeo Munbeobron-eui Ihae. Gaemunsa. 
LiNGUA Vol. 16, No. 2, December 2021 • ISSN 1693-4725 • e-ISSN 2442-3823 